\title{
MEMBANGUN CLOUD COMPUTING UNTUK MANAGEMEN DATA PADA UNIVERSITAS ISLAM LAMONGAN
}

\author{
Agus Junaidi ${ }^{1}$, Retno Wardhani ${ }^{2}$, Masruroh ${ }^{2}$ \\ 1) Program Studi Teknik Informatika, Fakultas Teknik, Universitas Islam Lamongan \\ ${ }^{2)}$ Dosen Program Studi Teknik Informatika, Fakultas Teknik, Universitas Islam Lamongan \\ E-mail:argasj@yahoo.co.id ${ }^{1}$,retzno@yahoo.com ${ }^{2}$,ismi_masruroh@yahoo.com ${ }^{3}$
}

\begin{abstract}
To improve the efficiency of work activity management at Islamic University of Lamongan requires a service system that can help the work of management, especially data management service / file then the wake of data management services with website technology built in network of private University, website service is in the cloud Computing Local Service was built from a virtual server with a Debian 8 operating system and a server residing within the Proxmox operating system. The stages of the development of this service system include the creation of cloud services is done through several stages, namely the stage of network design, the stage of installing the operating system Proxmox, the stage of creating a VE server in proxmox, the stage of installing the VE server with debian8, the stage of configuring the VE server to web server and domain Server, implementation and testing stages. And also the stages of making management services through several stages, namely the design phase of the context diagram, the phase make usecase service diagram, create an activity diagram, the stage of making sequence diagram, and interfaces design stage.
\end{abstract}

Keywords: Cloud, Intranet, Website, Managemen, File

\section{PENDAHULUAN}

Meningkatnya aktifitas data terutama pada manajemen di Universitas Islam Lamongan membuat aktifitas pengelolahan data membutuhkan waktu yang sangat cepat, tepat dan efesien dalam penyampaian data informasi, terutama pada informasi pada kepegawaian dan akademik. Terlebih dengan keakuratan penyampaian informasi data pada masingmasing fakultas yang membawahi masingmasing prodi dan setiap fakultas mempunyai masing-masing tata usaha dalam struktur manajemenya. Penyampaian informasi selama ini sudah bekerja dengan baik tetapi kurang efesien karena tersampainya informasi yang di berikan oleh pemberi informasi belum bisa dikontrol dengan baik apakah sudah tersampaikan kepada penerima informasinya atau tidak. Hal tersebut dikarenakan tidak ada feedback atau tanda informasi diterima atau terbaca oleh setiap masing-masing petugas yang bekerja di bidangnya masing-masing.
Data dan informasi tersampaikan dengan waktu yang relatif lama hingga beberapa hari untuk sampai atau di terima oleh penerima informasi, selama ini hal tersebut masih menjadi kendala bagi masing-masing fakultas karena data berbentuk hardcopy sehingga membutuhkan akses data secara manual, dengan perlu mencetak data terlebih dahulu oleh bagian yang mau memberikan informasi data, dan bagian penerima data informasi harus mendatangi data dan baru bisa mendapatkan data informasi tersebut, hal ini bisa dipersingkat tentunya dengan menggunakan teknologi manajemen data dengan menggunakan jaringan komputer yang telah di bangun pada Universitas Islam Lamongan, dengan memanfaatkan teknologi web maka semua bagian setiap bagian dari fakultas yang membawai masing-masing prodi dan mempunyai masing-masing tata usaha bisa mengirim data menerima data berupa softcopy secara real time / tidak membutuhkan waktu yang lama. 
Selama ini kendala yang di alami antara lain, penyimpanan data tidak otomatis, resiko data hilang, dan rusak karena waktu masih menjadi kendala.

Layanan manajemen data dapat meningkatkan efesiensi pekerjaan dari setiap bagian pada masing-masing fakultas yang ada di Universitas Islam Lamongan, karena sistem bisa merekam $\log$ atau aktifitas setiap bagian yang melakukan aktifitas memberikan atau menerima informasi. Penerapan teknologi manajemen data dalam cloud computing pada intranet di Universitas Islam Lamongan merupakan terobosan yang sangat di butuhkan oleh manajemen pada Universitas karena mengingat pekerjaan manajemen pada Universitas sangat banyak dan dengan data yang jumlahnya sangat banyak untuk di olah, penambahan sistem manajemen data ini di rasa tepat dengan di bangun pada sistem jaringan yang telah ada.

\section{Komputasi Awan}

Menurut Institut Nasional Standar dan Teknologi, komputasi awan didefinisikan sebagai "model untuk meningkatkan kenyamanan, memberikan ondemand access ke jaringan terminal sumber daya komputasi bersama, yang dapat dikonfigurasi (misalnya jaringan, server, penyimpanan, aplikasi, dan layanan yang diberikan) yang dapat ditetapkan dengan cepat dan dirilis dengan upaya manajemen atau interaksi penyedia layanan yang minimal. Komputasi awan mengacu pada layanan penyampaian aplikasi melalui internet dan perangkat keras serta sistem perangkat lunak di pusat data sebagai penyedia layanan [1].

\section{PERANCANGAN PROSES}

Perancangan proses merupakan tahapan yang dilakukan untuk mengekspresikan sebuah proses yang akan berjalan di dalam sistem dalam bentuk diagram-diagram yang mewakili bagaimana sistem tersebut bisa bekerja, juga menggambarkan hubungan sistem dengan pengguna, dan informasi yang akan di dapat oleh pengguna layanan sistem.

\section{Use case diagram}

Use case diagram adalah gambaran graphical dari beberapa atau semua actor, usecase, dan interaksi diantara komponenkomponen tersebut yang memperkenalkan suatu sistem yang akan dibangun. Use case diagram menjelaskan manfaat suatu sistem jika dilihat menurut pandangan orang yang berada di luar sistem. Diagram ini menunjukkan fungsionalitas suatu sistem atau kelas dan bagaimana sistem tersebut berinteraksi dengan dunia luar.

Kebutuhan sistem dari sudut pandang user adalah rangkaian atau uraian sekelompok yang saling terkait dan membentuk sistem secara teratur yang dilakukan atau diawasi oleh sebuah aktor. Umumnya use case digambarkan dengan sebuah elips dengan garis yang solid, biasanya mengandung nama.

Use Case dengan user akun dekan

Berikut ini adalah gambar diagram Use Case dengan akun user dekan. 


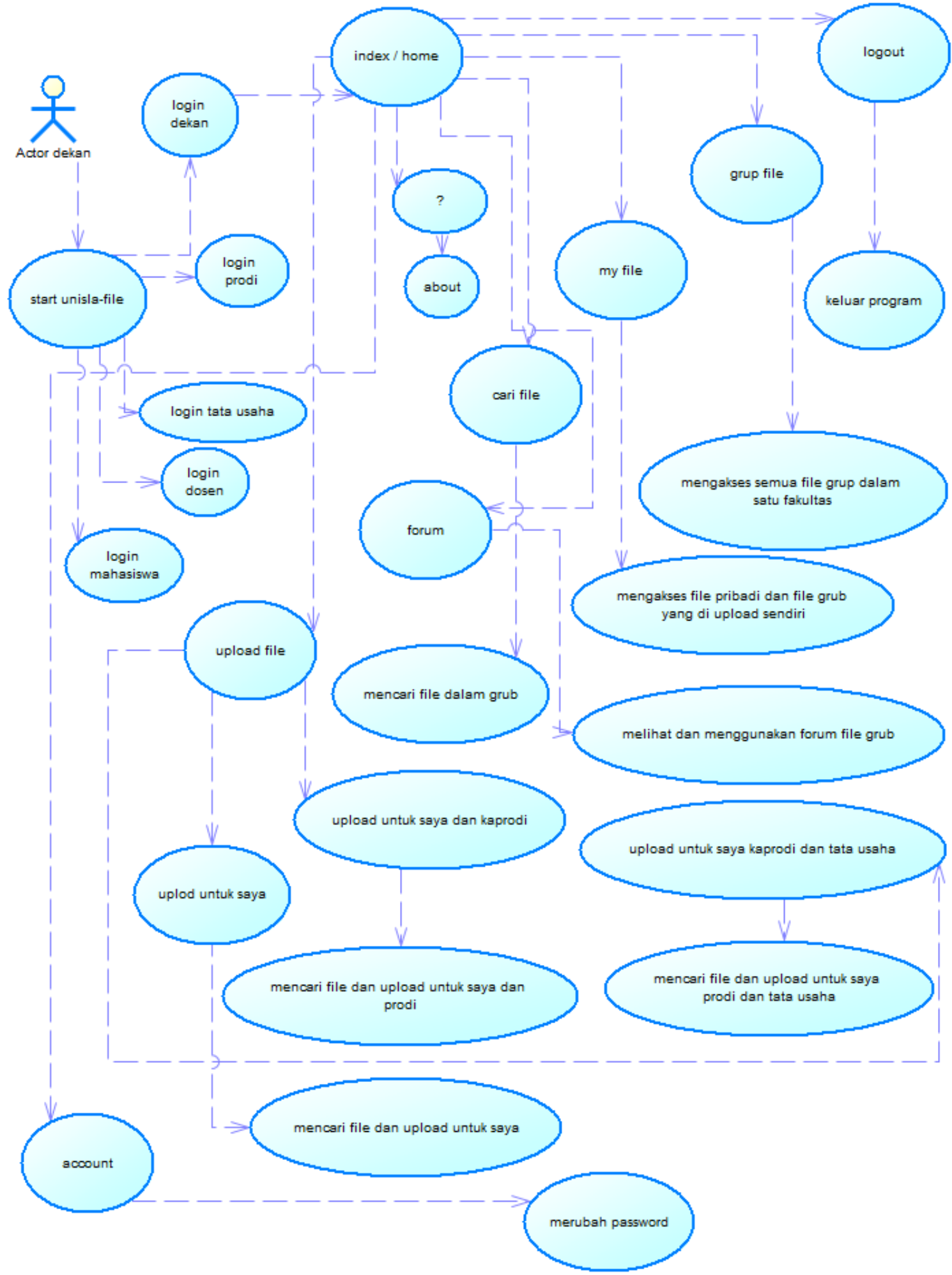

Gambar 1. Usecase Akun Dekan

\section{Activity diagram menu utama}

Diagram aktivitas atau dalam bahasa inggris activity diagram adalah representasi grafis dari seluruh tahapan alur kerja. Diagram ini mengandung aktivitas, pilihan tindakan, perulangan dan hasil dari aktivitas tersebut. Pada pemodelan UML, diagram ini dapat digunakan untuk menjelaskan proses bisnis dan alur kerja 
operasional secara langkah demi langkah dari komponen suatu sistem.

Activity diagram menu utama merupakan gambaran dari aktifitas yang di lakukan oleh pengguna dan bagaimana program dari sistem layanan manajemen data melakukan proses yang di lakukan oleh sistem di bagian menu utama rogram, sehingga dapat di ketahui bagaimana sistem pelakukan proses di balik layar yang tidak di ketuhi oleh pengguna layanan manajemen data.

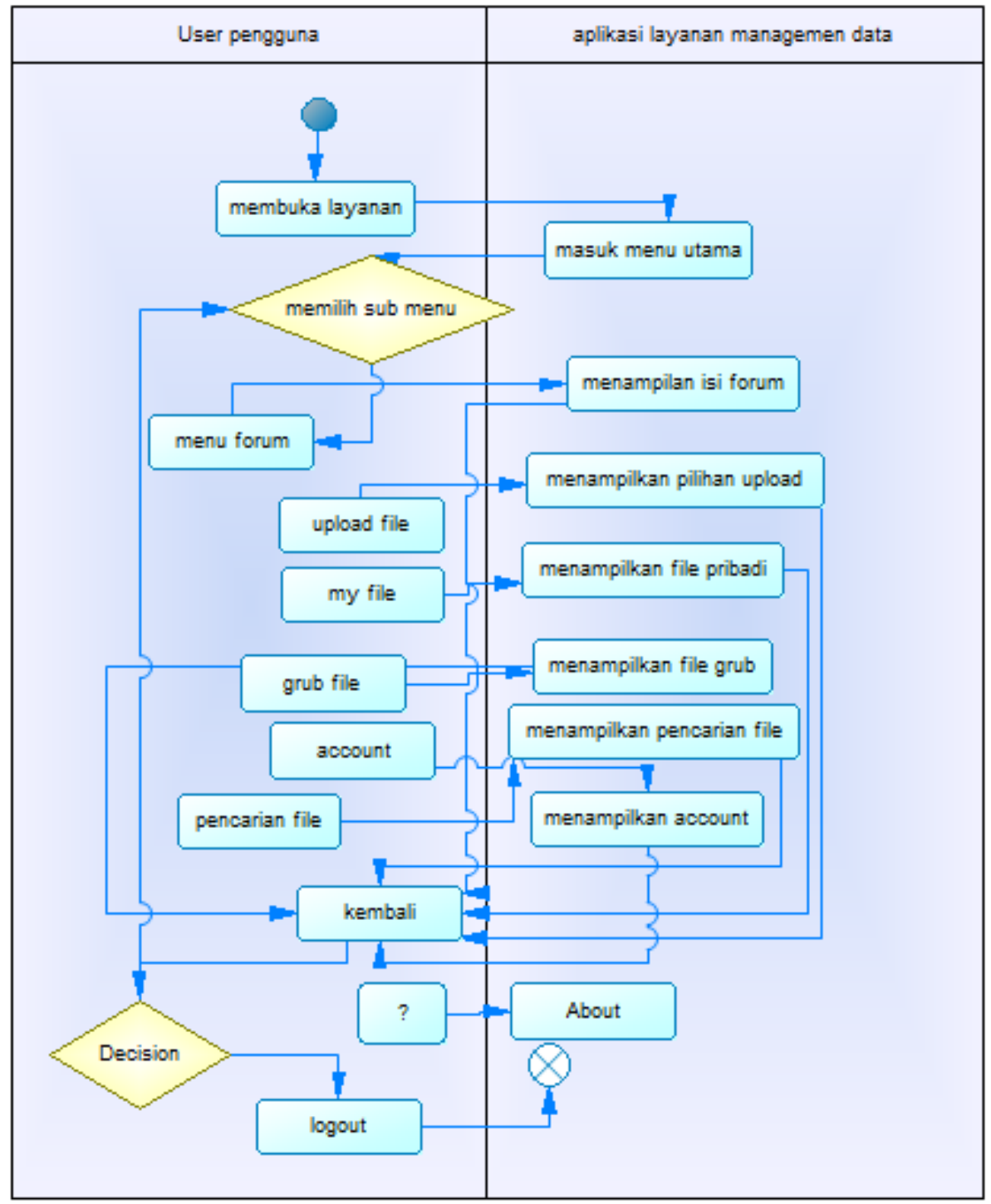

Gambar 2. Activity Menu Utama

\section{Sequence diagram}

Pada tahap ini di asumsikan user akun sudah melakukan login dan berhadapan dengan menu home atau menu utama, dari menu utama user di hadapkan beberapa menu yaitu forum, upload file, my file, grup file, cari file, account dan logout.

Sequence diagram menu utama 


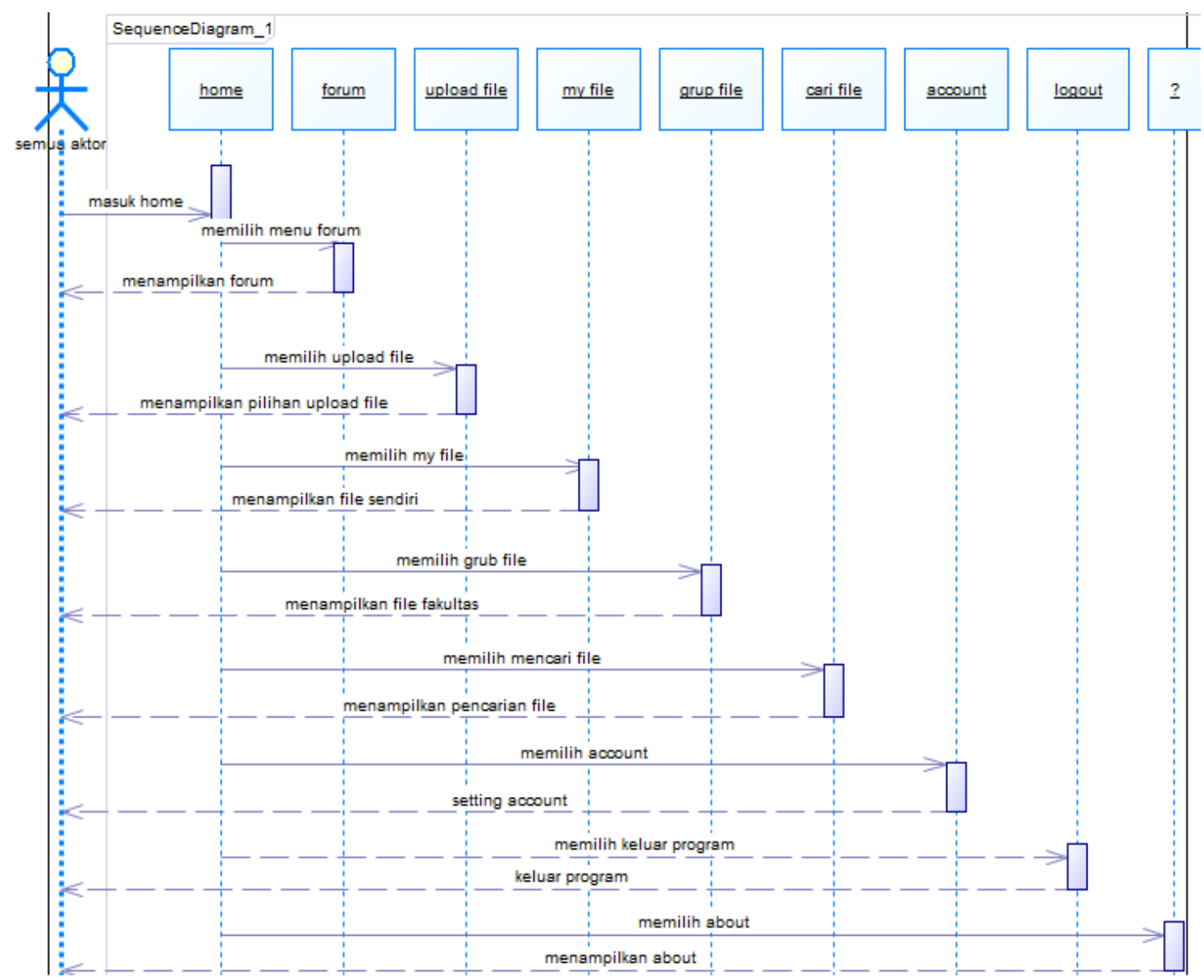

Gambar 3. Sequence Diagram

\section{IMPLEMENTASI}

Dalam bab ini merupakan pemaparan implementasi dan analisis hasil uji coba layanan cloud computing dan layanan manajemen data. akan di paparkan hasil-hasil dari tahapan penelitian, tahap analisis, tahap desain, implementasi desain, hasil testing, dan implementasinya, baik secara kualitatif maupun kuantitatif.

\section{Implementasi}

Implementasi ialah tahapan dimana setelah melakukan sebuah analisa dan perancangan sistem, sistem layanan manajemen data diharapkan mampu untuk dioperasikan secara maksimal dan pada kondisi yang sebenarnya di dalam layanan cloud computing. Oleh sebab itu cloud computing maupun sistem layanan manajemen data yang sudah dibuat harus sesuai dengan apa yang sudah dirancang sebelumnya, aplikasi dan sistem aplikasi tersebut juga harus mampu berjalan dengan baik dan dalam keadaan peforma yang baik pula.

\section{Menu Konfigurasi Cloud Computing}

Setting up dan uji coba layanan cloud computing

Untuk memastikan sistem layanan cloud berjalan dengan baik dan bisa berfungsi dengan normal untuk dapat di gunakan sebagai tempat server layanan manajemen data di Universitas Islam Lamongan maka perlu dilakukan pengujian, dan beberapa proses pemeriksaan hasil konfigurasi yang telah di lakukan terhadap sistem operasi server di mana sebagai tempat layanan manajemen data tersebut, dengan beberapa konfigurasi di antaranya memasang dan mengkonfigurasi web server dan pemasangan dan konfigurasi dns server. dari beberapa hal yang perlu di lakukan di antaranya memasang php5 pada sisi server dan memasang mysql server juga mysql client untuk fungsi database yang berada di sisi server, dengan memudahkan konfigurasi database menggunakan mode grafik / gui juga bisa di 
pasang phpmyadmin di sisi server, sehingga memudahkan dalam melakukan setting up database untuk layanan manajemen data yang ada di server tempat layanan manajemen data.

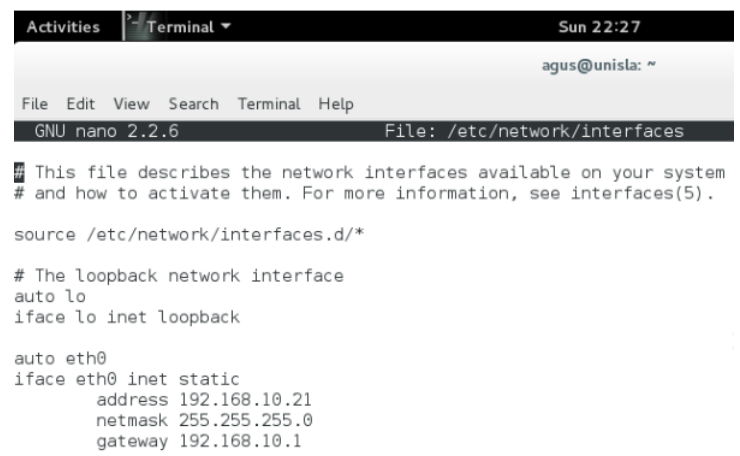

Gambar 4. Konfigurasi Ip Address Server

Konfigurasi lanjutan untuk DNS server dengan alamat www.data-unisla.id dari ip address 192.168.10.21/24 dari file ip yang berada di "/etc/bind/ip".

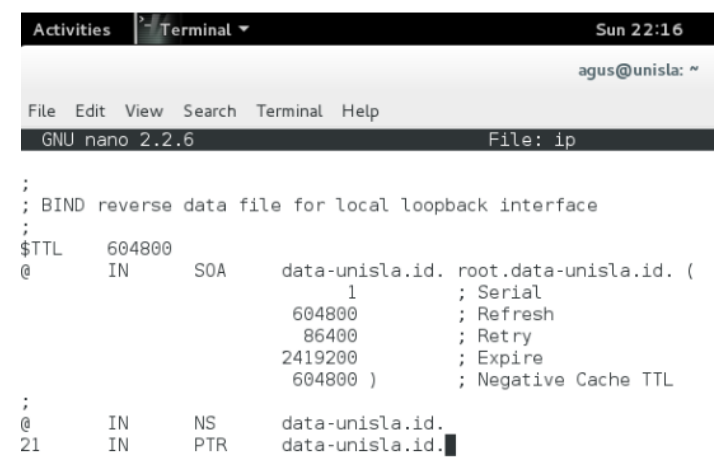

Gambar 5. Konfigurasi Nano /etc/bind/ip

\section{Manual sistem layanan manajemen data}

Manual dari sistem layanan manajemen data ini berisi tentang petunjuk cara penggunaan dari layanan sistem manajemen data, agar pengguna dari sistem layanan manajemen data tidak menemukan kesulitan saat menggunakan sistem ini, dan di harapkan user pengguna dapat menggunakan layanan dengan benar dan dapat mengetahui fungsi dari setiap fitur yang ada di dalam layanan manajemen data pada Universitas Islam Lamongan.

Saat pertama masuk layanan maka akan di tampilkan halaman Start-UnislaFile untuk memulai menjalankan layanan, klik tulisan Start-UnislaFile.

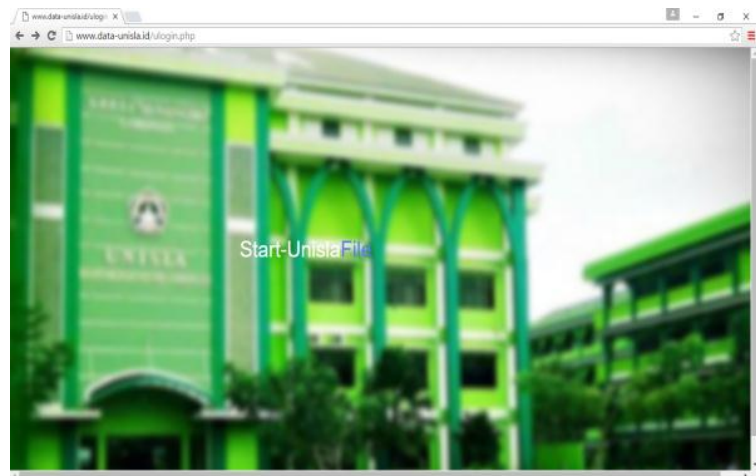

Gambar 6. Start-unisla file

Setelah memilih Start unisla file maka akan mengalihkan halaman ke halaman login untuk user sesuai dengan level masing-masing user.

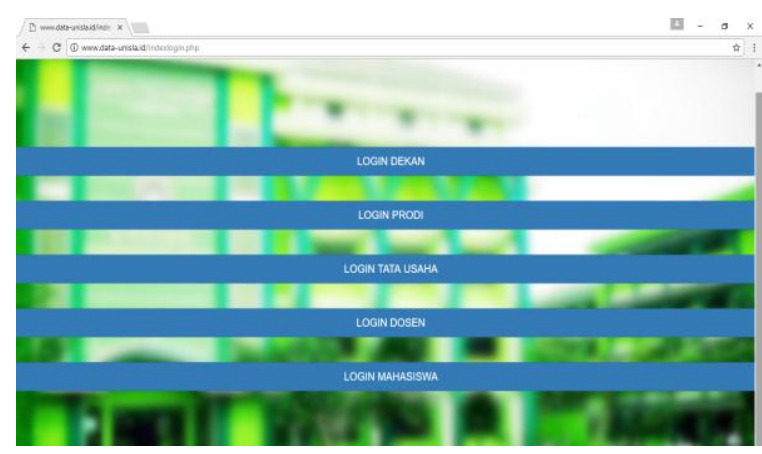

Gambar 7. Opsi login

Setelah memilih salah satu dari pilihan login sesuai dengan level maka akan mengalihkan ke halaman login dengan menampilkan isian username dan isian password, disini di asumsikan memilih login sebagai dekan.

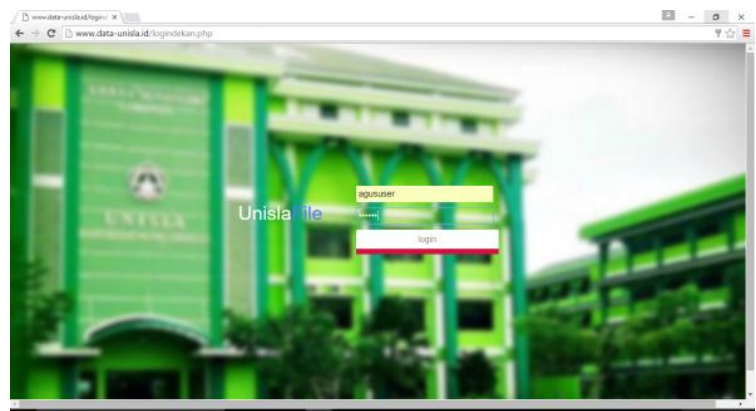

Gambar 8. Login

Setelah memasukan username dan password dengan benar dan menekan tombol login, maka akan berhasil masuk ke halaman home dari layanan manajemen data. 


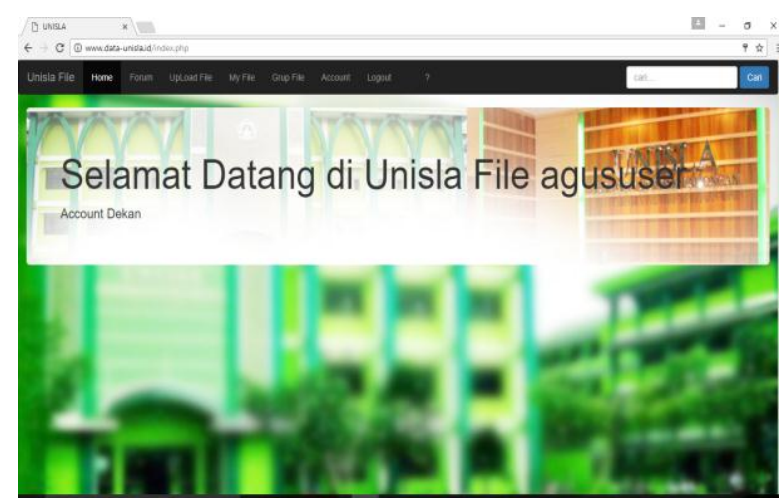

saat memilih menu my file maka akan menampilkan file yang telah kita upload, didalam my file user bisa melakukan download file dan detail file untuk melihat user yang telah men-download file.

Gambar 9. Halaman Home

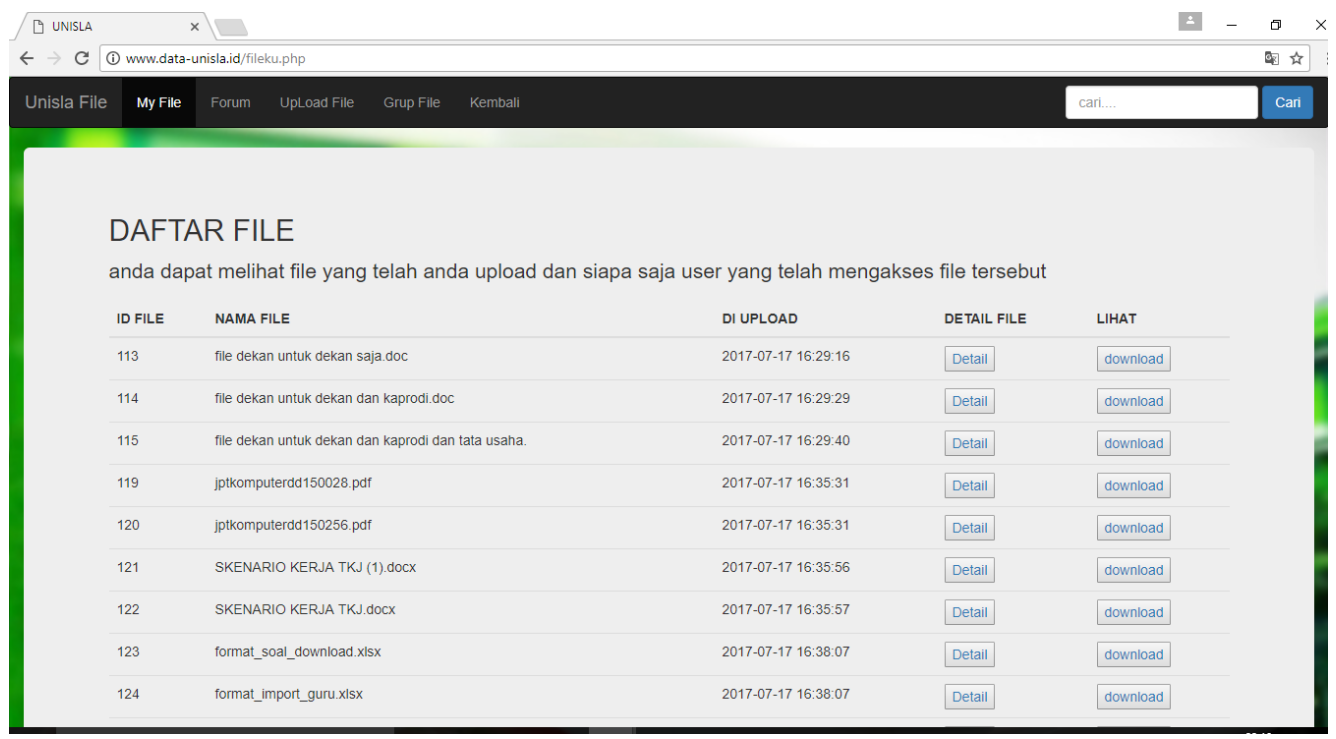

Gambar 10. Halaman my file

Menu upload file, saat memilih menu upload file maka akan menampilkan opsi pilihan upload

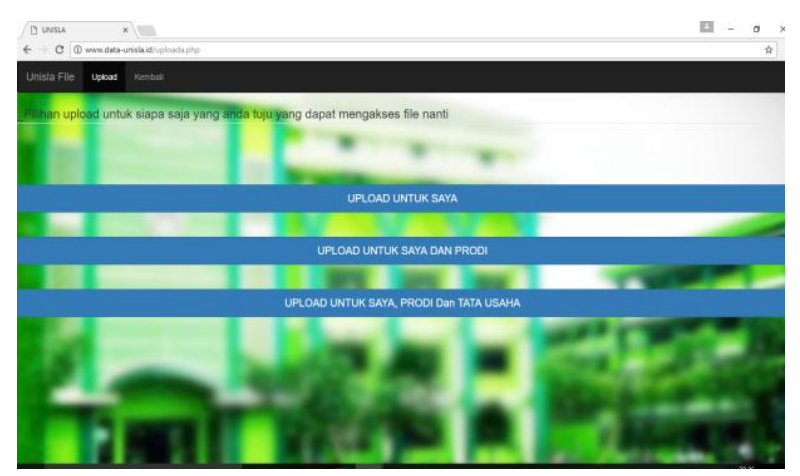

Gambar 11. Opsi upload

Untuk login sebagai administrator atau admin dari layanan sistem manajemen data ini, untuk siapa saja sebagai penerima yang di tuju dari file tersebut untuk dapat mengaksesnya. harus mengetikan extensi alamat "/loginadmin" di "www.data-unisla.id" menjadi "www.dataunisla.id/loginadmin" karena untuk alasan keamanan login, dan maka langsung di hadapkan dengan tampilan login admin, username dengan root dan password yang telah di tentukan sebelumnya.

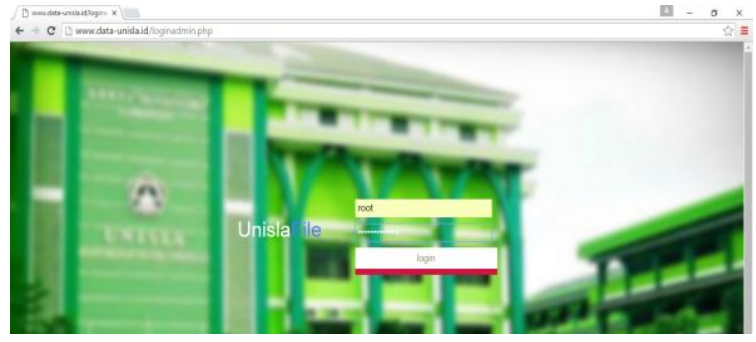

Gambar 12. Halaman login admin 
Setelah root dan password yang di masukan benar maka akan mengalihkan ke halaman Administrator / Root.

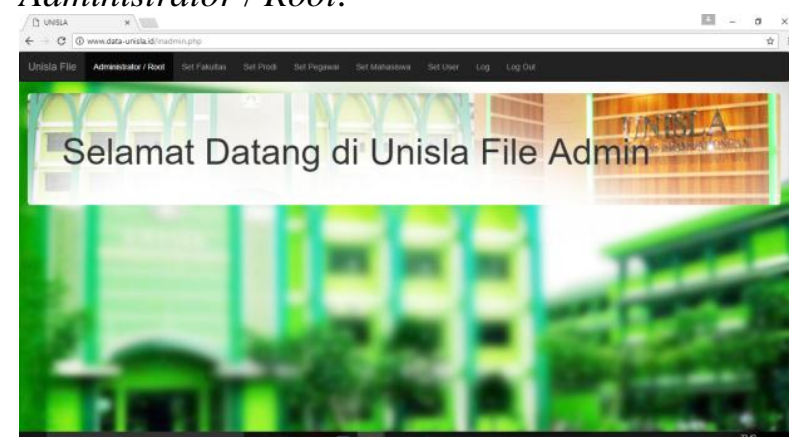

Gambar 13. Halaman admin

Menu $\log$ berfungsi untuk menampilkan log aktifitas dari rekaman user yang menggunakan layanan manajemen data ini, aktifitas login dan logout, juga aktifitas user yang melakukan perubahan pada password akun yang di miliki.

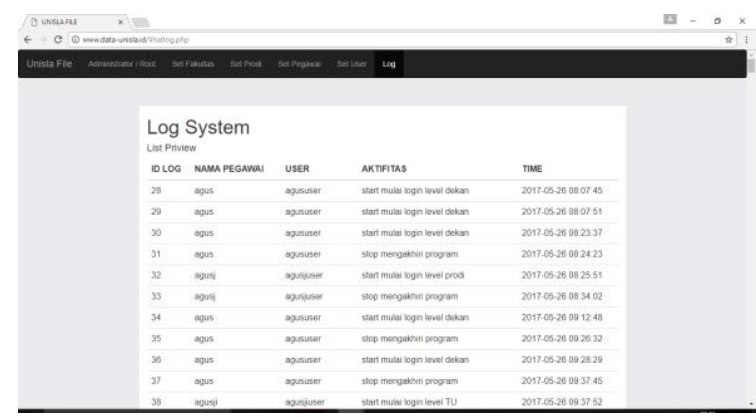

Gambar 14. Halaman $\log$ file

\section{PENUTUP}

Setelah melalui beberapa proses panjang dan tahapan dalam menyelesaikan membangun cloud computing untuk manajemen data pada Universitas Islam Lamongan. Dapat disimpulkan bahwa : Membangun cloud computing dilakukan melalui beberapa tahap, yaitu tahap desain jaringan, tahap menginstall sistem operasi Proxmox, tahap membuat server $V E$ di dalam proxmox, tahap menginstall server $V E$ dengan debian8, tahap mengkonfigurasi server VE menjadi web server dan domain server, tahap implementasi dan pengujian.

Membangun layanan manajemen data di lakukan melalu bebererapa tahap, yaitu tahap desain diagram konteks, tahap membuat usecase diagram layanan, membuat actifity diagram, tahap membuat diagram sequence, dan tahap perancangan antar muka (interfaces).
Memasang layanan manajemen data pada layanan cloud computing dengan melakukan upload website layanan manajemen data ke server debian8 yang berada di layanan cloud computing dari server Proxmox, dari sisi komputer client dengan menggunakan program WinSCP, makan layanan dapat di buka dari jaringan yang bisa terhubung dengan server dengan alamat www.data-unisla.id.

\section{REFERENSI}

[1] Budi Harijanto dan Yuri Ariyanto, 2015, Desain Dan Analysis Kinerja Virtualisasi Server Menggunakan Proxmox Virtual Environment, Jurnal, Manajemen Informatika, Politeknik Negeri Malang, Malang.

[2] Jerry Stover Tangaguling dkk, 2012, Perancangan dan Pembuatan Aplikasi Monitoring Traffic Jaringan Intranet Berbasis Web Dengan Menggunakan Protokol SNMP, Jurnal, Teknik Elektro, Institut Teknologi Nasional Malang.

[3] Wibowo Agung, 2011 Penerapan Komputasi Awan Dalam Dunia Pendidikan - Sebuah Pendekatan Teoritis, Jurnal, STMIK Nusa Mandiri, Sukabumi. 